\title{
The Benefits of Being Understood: The Role of Ethnic Identity Confirmation in Knowledge Acquisition by Expatriates
}

Shea X Fan

Christina Cregan

Anne-Wil Harzing

Tine Köhler

Version May 2017

Accepted for Human Resource Management

Copyright @ 2017, Shea X Fan, Christina Cregan, Anne-Wil Harzing, and Tine Köhler

\author{
All rights reserved. \\ Prof. Anne-Wil Harzing \\ Middlesex University \\ The Burroughs, Hendon \\ London NW4 4BT \\ Email: anne@harzing.com \\ Web: www.harzing.com
}




\title{
The Benefits of Being Understood: \\ The Role of Ethnic Identity Confirmation in Knowledge Acquisition by Expatriates
}

\author{
Shea X. Fan \\ School of Management, RMIT University \\ Building 80, 445 Swanston Street, Melbourne, Australia, 3000 \\ Telephone: 0061399255812 \\ Fax: 0061399255952 \\ Email: shea.fan@rmit.edu.au \\ Nottingham University Business School China \\ University of Nottingham Ningbo China \\ 199 Taikang East Road, Ningbo, China, 315100 \\ Christina Cregan \\ Department of Management and Marketing \\ The University of Melbourne \\ 198 Berkeley Street, Level 10 \\ Parkville, VIC 3010, Australia \\ Telephone: +61383445257 \\ Fax: +61393494293 \\ Email: ccregan@unimelb.edu.au \\ Anne-Wil Harzing \\ Business School \\ Middlesex University London \\ The Burroughs, London, NW4 4BT \\ Email: anne@harzing.com \\ Tine Köhler \\ Department of Management and Marketing \\ The University of Melbourne \\ 198 Berkeley Street, Level 10 \\ Parkville, VIC 3010, Australia \\ Telephone: +61390355852 \\ Fax: +61 393494293 \\ Email: tkoehler@unimelb.edu.au
}




\begin{abstract}
In this paper, we propose that the concept of ethnic identity confirmation (EIC), the level of agreement between how expatriates view the importance of their own ethnic identity and how local employees view the importance of expatriates' ethnic identity, can explain why expatriates who are ethnically similar to host country employees are sometimes less effective than expected when working overseas. Multinationals often choose ethnically similar expatriates for international assignments, assuming these expatriates can more effectively acquire knowledge from local employees. Thus, understanding the specific challenges that endanger the realization of this potential is crucial.
\end{abstract}

Our survey, administered to a sample of 128 expatriate-local employee dyads working in China, reveals that both ethnically similar and ethnically different expatriates acquire more local knowledge when EIC is high. However, the association between ethnic (dis)similarity and knowledge acquisition is direct for ethnically different expatriates, whereas for ethnically similar expatriates it is indirect via their perception of local employees' trustworthiness. We discuss this study's important implications and provide recommendations for multinationals on how to provide tailored support to expatriates who face different identity challenges.

Keywords: International HRM, social identity theory, trust, knowledge management, diversity 


\section{Introduction}

Given the potential organizational and personal costs associated with unsuccessful expatriate assignments, including, but not limited to, poor performance (Dowling, Festing, \& Engle, 2008), low job satisfaction (Reiche, 2007), premature return (Harzing, 1995), or leaving the organization (Shaffer \& Harrison, 1998), researchers have focused on identifying factors that might increase the likelihood of success for expatriates on international assignments. The role of local employees, in particular, has gained increasing attention (Mahajan \& Toh, 2014; Toh \& DeNisi, 2005; Vance, Vaiman, \& Andersen, 2009). Local employees who interact with expatriates on a daily basis can help them achieve business goals and can provide work and non-work related information and support (Shen \& Kram, 2011; Toh \& DeNisi, 2007). However, they may also negatively influence expatriates' performance if they are unwilling to cooperate with expatriates (Toh \& DeNisi, 2005).

One stream of research trying to explain why local employees might not support expatriates from the angle of ethnic (dis)similarity in expatriate-local employee interactions. Researchers have found that ethnic dissimilarity can trigger out-group categorization, which could damage trust and inhibit interpersonal support, information sharing, and cooperative behaviors (Mäkelä, 2007; Toh \& DeNisi, 2007; Varma, Pichler, \& Budhwar, 2011a). These findings align with self-categorization theory, suggesting in-group categorization facilitates interpersonal interactions (Brewer \& Pierce, 2005). In fact, many MNCs assign expatriates who share the same ethnicity as the local employees (called ethnically similar expatriates in this article) to local subsidiaries, believing these expatriates will be more effective than ethnically different expatriates. Although we are not aware of any official statistics on this, researchers have identified that this is a prevalent practice, especially in subsidiaries located in emerging economies such as India and China (Björkman \& Schapp, 1994; Goodall \& Warner, 1998; Thite, Srinivasan, Harvey, \& Valk, 2009). However, ethnic similarity has also been found to be associated with distrust, conflicts, and negative feelings. Which researchers have attributed these to expatriates' unrealistic expectations or unequal organizational policies (Hung, 1994; McEllister, 1998; Selmer \& Shiu, 1999).

Different from previous research, though, we argue that the contradictory findings concerning the role of ethnic similarity are because current research has overlooked the complicated role it plays in social interactions. Ethnic similarity is based on objective ethnicity. In social interactions, people's (i.e., expatriates') objective ethnicity tends to have a strong influence on the cognitions of the perceiver (i.e., local employees), such as making ethnicity-based in-group categorizations (Ashforth \& Mael, 1989), and assuming the 
ethnicity-based identity to be important to their counterpart (Barreto \& Ellemers, 2003). However, what affects the focal person (i.e., expatriates) most, tends to be their subjective view toward their own ethnic membership (i.e., ethnic identity) (Barreto \& Ellemers, 2003). Ethnically similar expatriates do not necessarily view their ethnic identity as important (Alderfer \& Thomas, 1988; Stryker \& Serpe, 1994). In such cases, these expatriates might, therefore, not view local employees as ethnic in-groups. As a result, expatriates and local employees may hold different views concerning the importance of expatriates' ethnic identity, and this perceptual disagreement may undermine the potential social benefits of ethnic similarity.

To capture this potential perceptual (dis)agreement, we introduce the concept of ethnic identity confirmation (EIC), referring to the level of agreement between how one party (i.e., an expatriate) views the importance of his/her own ethnic identity and how the importance of this identity is viewed by other people (i.e., local employees) (Milton \& Westphal, 2005; Thatcher \& Greer, 2008). When expatriates achieve a high level of ethnic identity confirmation, their ethnic similarity with local employees might positively influence their social interactions; in contrast, a low level of confirmation might undermine the benefits of ethnic similarity for expatriates.

In the remainder of this paper, we start with a critical review of the existing research on ethnic (dis)similarity in the expatriate and identity confirmation literature. We highlight the problems by outlining assumptions and explain how our research contributes to addressing these problems. Following this, we develop a model explaining how expatriates' EIC interacts with ethnic (dis)similarity to influence important outcomes of expatriation. After describing the methodology and sample, we present our findings. Finally, we discuss how our research contributes to the development of the expatriate and identity confirmation literatures and how it underscores the importance of identity in expatriate management.

\section{Ethnic Similarity Research: A Critical Review of the Expatriate Literature}

In the management literature, the social benefits of demographic similarity, such as increasing interpersonal attraction, facilitating friendship, and encouraging communication, have been well documented (Chattopadhyay, Tluchowska, \& George, 2004; Tsui \& O'Reilly, 1989; Tsui, Porter, \& Egan, 2002). These findings also receive support from the expatriate literature, in which much research has focused on expatriates that are ethnically different from local employees. Applying social identity theory and selfcategorization theory, this literature has documented how out-group categorization might become a barrier for expatriates to gain support and information from local employees. Local employees might categorize expatriates as out-group members based on surface- 
level differences such as ethnicity and might be reluctant to provide role information, share knowledge or give social support (Mäkelä, Andersson, \& Seppälä, 2012; Pichler, Varma, \& Budhwar, 2012; Toh \& DeNisi, 2007; Varma, Pichler, \& Budhwar, 2011b). This suggests ethnically similar expatriates will experience fewer problems because of the ethnic ingroup characterization by local employees. Nevertheless, research on ethnically similar expatriates contradicts these findings. Research reveals that some ethnically similar expatriates view local employees as hostile and not trustworthy (Hung, 1994; McEllister, 1998). Some complained that they were disliked (Björkman \& Schapp, 1994), envied (Selmer \& Shiu, 1999), or even resented by local employees (Goodall \& Warner, 1998). These negative perceptions might easily result in communication barriers and inhibit expatriates from fulfilling their organizational mission of gaining knowedge from local employees.

To explain why ethnic similarity does not always generate the expected social benefits, we need to examine prevailing assumptions in the current expatriate literature. The first assumption is that expatriates view their ethnic identity as important and that this identity guides their attitudes or behaviors. Social identity theory (Tajfel, 1981) and selfcategorization theory (Turner, 1982), however, postulate that individuals belong to multiple social groups and have multiple social identities (Ashforth \& Mael, 1989) that may conflict with each other and signal contradicting behavioral instructions (Burke, 2003). Social identity theory acknowledges an individual's freedom in determining which identity is important in a given situation (Ashmore, Deaux, \& McLaughlin-Volpe, 2004). Which identity individuals choose to focus on is based on its personal importance or situational relevance (Ashforth \& Johnson, 2001) and ethnically similar expatriates might not necessarily view their ethnic identity as personally important or situationally relevant. When interacting with local employees, they might want to stress their work identities, such as their identity as a manager, team leader, or a professional. In this case, ethnic similarity will not generate the expected social benefits.

The second issue relates to the current literature's neglect of the fact that when expatriates interact with local employees, the role of expatriates' ethnicity is complicated. On the one hand, the expatriate might not necessarily view their ethnicity-based ethnic identity as important. On the other hand, their objective ethnicity is likely to be salient in the eyes of local employees in an environment in which multiple ethnic identities co-exist (Ashforth \& Johnson, 2001; Ashforth \& Mael, 1989). The salience of expatriates' ethnicity might prevent local employees from recognizing expatriates' other identities and, consequently, influence local employees' social expectations (Ramarajan, 2014). For example, in the eyes of local employees, the ethnicity of ethnically similar expatriates is likely to be salient because it is usually visible and forms a contrast with ethnically different expatriates. Based on selfcategorization theory (Turner, 1982), a salient ethnic identity primes local employees to 
make an ethnicity-based social categorization of expatriates. This will lead them to view ethnically similar expatriates as ethnic in-groups, which, in turn, generates expectations that expatriates will follow ethnic cultural norms or demonstrate in-group favoritism as predicted by social identity theory (Brewer, 1979). Local employees may further assume that ethnic identity is equally important to the ethnically similar expatriates.

Taking together the arguments in the two previous paragraphs, local employees may view expatriates' ethnic identity very differently from how expatriates view their own identity. The psychological processes underlying identity perceptions are different for local employees and for expatriates, resulting in potentially very different assumptions. These, in turn, are likely to influence interactions between them and may help explain the inconclusive findings in previous research on the challenges ethnically similar expatriates face when interacting with local employees.

The third issue we intend to address relates to an unbalanced examination of expatriatelocal employee interactions. The current literature tends to simplify the situation by focusing on only one social party's experiences, usually the local employees' categorization of expatriates and their willingness to support expatriates (Bonache, Langinier, \& ZárragaOberty, 2016; Pichler et al., 2012; Toh \& DeNisi, 2007). Previous research seems to assume that as long as local employees are willing to support expatriates, their relationship with expatriates will be positive. However, the literature ignores the fact that to establish positive expatriate-local employee relationships, expatriates also play a role. If expatriates do not consider local employees as trustworthy, their interactions with local employees might not contribute positively to their performance.

The concept of expatriates' EIC can address the problems we have identified. It integrates the views of expatriates and local employees into one concept. On the one hand, it takes expatriates' individual differences into consideration and does not assume that all expatriates view their ethnic identity as important. On the other hand, it does not assume the views of either expatriates or local employees alone will determine the outcome of their interactions. Instead, EIC acknowledges that incongruent views may exist between these two parties and that the level of congruence can affect interactions between expatriates and local employees. Finally, by focusing on expatriates' EIC, we provide valuable information about expatriates' experiences when interacting with local employees, an area rarely explored in expatriate research. 


\section{Ethnic Identity Confirmation: Theoretical Foundations}

The concept of expatriates' EIC has two theoretical foundations. One is self-verification theory. This contributes the first key element of this concept, namely perceptual congruence. A high level of confirmation is achieved when both parties believe the expatriate's ethnic identity is important or when both view it as not particularly important. A lack of confirmation refers to situations when the two parties hold divergent views. Thus, expatriates' EIC is determined by two pieces of information, namely the importance that expatriates attach to their own ethnic identity and the importance that local employees attach to the expatriates' ethnic identity. Levels of confirmation can be computed as long as we know the views of both parties.

Self-verification theory explains why identity confirmation is important to expatriates. This theory assumes that searching for coherence is a fundamental human desire (Swann, Rentfrow, \& Guinn, 2003). One source of coherence is to have a stable self-definition (Cooley, 1983; Polzer, Milton, \& Swann, 2002). However, as we discussed earlier, although the focal individuals (i.e., expatriates) have the freedom to decide whether or not their ethnic identity is important, in social interactions, the perceivers (i.e., local employees) also have freedom in assessing the level of importance of the focal person's ethnic identity. Thus, both views need to be considered in order to predict the outcome of their social interactions. When incongruent views occur, it can cause feelings of frustration (Swann et al., 2003) because they challenge the focal person's basic self-view (or identity), a meaning system which tells people who they are, how they should behave and how they are related to others (Seyle \& Swann, 2007). In contrast, when agreement is achieved, individuals can gain positive feelings about themselves, such as being in control and being accepted (Swann et al., 2003); it can also generate positive feelings about others, helps to develop confidence in such relationships and makes people more willing to commit to those relationships (Burke \& Stets, 1999). Consequently, individuals tend to communicate more with people who verify their identity (Swann et al., 2003).

Social identity and self-categorization theory contribute to the content of perceptual congruence, which is the second key element of expatriates' EIC. These theories provide the basis for why the perceived importance of ethnic identity is contested. When people seek confirmation of personal identity, they contest whether or not a person has certain personal characteristics (Milton \& Westphal, 2005; Swann \& Ely, 1984). For example, for people who view being creative (or not creative) as one of their personal characteristics, identity confirmation occurs when others also attribute creativity (or lack of creativity) to them. When it comes to social identity, what is contested is not whether or not the expatriate has the ethnic group membership, because an ascribed identity cannot be imposed or denied. However, what can be negotiated is whether or not the ascribed 
identity should guide the interaction and, more specifically, how important the focal ethnic identity is deemed to be. As discussed previously, to avoid conflicting norms and demands related to multiple social identities, individuals tend to focus on an identity subjectively important or situationally relevant to them at a particular time (Ashforth \& Johnson, 2001). Taking ethnic Chinese expatriates as an example, they might not view their ethnic identity as important. They might think that "I am ethnic Chinese, but this identity is not important to me at work. I want to be seen as a professional, and prefer to follow professional norms". Nevertheless, in the eyes of local employees the salience of expatriates' ethnic identity might suppress the perceived importance of their other identities. Thus, local employees might think that "You are Chinese. This identity should be more important to you than other identities, so your behaviors should be guided by this identity".

EIC is a generic phenomenon. In a social interaction, it affects both social parties. When expatriates interact with local employees, both parties might desire to have their ethnic identity confirmed by the other party. However, due to different ethnic-cultural backgrounds and the organizational status of expatriates and local employees, these two identity confirmation processes might have different underlying mechanisms. For simplicity, in this paper we, therefore, only focus on expatriates' EIC. Additionally, EIC not only affects ethnically similar expatriate-local employee pairs but also affects ethnically different pairs. Thus, in the development of our hypotheses, we compare and contrast the effects of expatriates' EIC on the social interactions of both types of expatriate-local employee pairs.

\section{Ethnic Identity Confirmation and Expatriate-Local Employee Interactions}

One school of research on self-verification focuses on the consequences of self-verification. Specifically, researchers reveal its direct consequences on the target person's well-being (Swann et al., 2003); their attitudes towards others (Burke \& Stets, 1999) and communication with other people (Polzer et al., 2002; Seyle \& Swann, 2007; Thatcher \& Greer, 2008); as well as its indirect consequences on teams and organizations (Polzer et al., 2002; Seyle \& Swann, 2007; Thatcher \& Greer, 2008). Following this vein, we first investigated expatriates' attitudes towards local employees, specifically their evaluation of local employees' personal characteristics, such as benevolence or integrity (i.e. perceived trustworthiness), as the direct consequence of expatriates' EIC. Trustworthiness is an important factor in relationships between expatriates and local employees. It refers to people's cognitive evaluation of other people's personal characteristics that may provide justification for them to trust others (Colquitt, Scott, \& LePine, 2007). It is a key predictor of many positive workplace behaviors, such as more frequent interactions, communication and information sharing (Tsui et al., 2002). Based on social identity and self-categorization theories (Tajfel, 1981; Turner, 1982), ethnic similarity encourages ethnicity-based in-group 
categorization; thus, ethnically similar expatriates are expected to have an advantage over ethnically dissimilar expatriates in establishing positive relationships with local employees. However, for these advantages to materialize depends on whether or not expatriates can develop positive views towards local employees.

In addition, we explore the indirect impact of expatriates' EIC on an organizational level outcome, namely expatriates' knowledge acquisition from local employees. This is an important factor for both expatriates and MNCs. For expatriates, gaining knowledge about the host country's social, cultural and business environment provides an opportunity for personal development in terms of developing a global mindset, international leadership opportunities, or potential career prospects (Caligiuri \& Lazarova, 2001; Furuya, Stevens, Bird, Oddou, \& Mendenhall, 2009; Shaffer, Kraimer, Chen, \& Bolino, 2012). For MNCs, gaining host country knowledge through employing expatriates could be a corporate global strategy (Antal, 2001; Harzing, Pudelko, \& Reiche, 2015; Lazarova \& Tarique, 2005). To gain knowledge, expatriates need to recognize local employees as a knowledge source. They also need to interact and communicate with local employees. Expatriates' EIC is an important predictor for knowledge acquisition.

When developing hypotheses in each of the sections below, we follow the same order. First, we discuss the overall effects of high EIC (i.e. when ethnic identity is seen as either important or unimportant by both parties), then explain the interplay between high EIC and ethnic similarity, followed by a discussion on the effects of low EIC.

\section{Ethnic Similarity, Ethnic Identity Confirmation and Trustworthiness}

High EIC (i.e. when ethnic identity is seen as either important or unimportant by both parties) signals attitudinal congruence, which can give expatriates a feeling that their identity choice has been accepted and is respected by specific local employees (Polzer et al., 2002). This perception can encourage expatriates to form positive evaluations of local employees who confirm their identity. Furthermore, if confirmation occurs repeatedly through frequent interactions, expatriates can gain more knowledge about the local employees' personal characteristics (Burke \& Stets, 1999). For example, expatriates might believe local employees will act more benevolently towards them; they might also feel a high level of certainty when interacting with local employees because they know the principles local employees follow when they interact (Burke \& Stets, 1999). Thus, high EIC encourages expatriates to view local employees as trustworthy.

Ethnic similarity might strengthen the effects of high EIC. Expatriates might see ethnically similar local employees as ethnic in-group members. This psychological connection can encourage expatriates to see local employees as more trustworthy than out-groups. This is because people who associate themselves with their in-group are likely to make biased attributions towards their in-group members (Brewer, 1979; Tajfel, 1981; Tsui et al., 2002; 
Turner, 1982). The situation is different, however, for ethnically different expatriates. When both expatriates and local employees view expatriates' ethnic identity as highly important, this agreement could strengthen the perceived inter-group distinction and, in turn, strengthen distrust toward out-groups. Ethnic dissimilarity might discourage expatriates from perceiving local employees as trustworthy. Thereful, ethnic difference might mitigate the positive effect of high EIC for ethnically different expatriates.

Low EIC indicates divergent views toward what role expatriates' identity should play in their interactions, or an identity negotiation failure. Low EIC is likely to prevent both types of expatriates from viewing local employees as trustworthy. When people interact, especially at an early stage in a relationship, they will experience a conscious or subconscious identity negotiation process (Polzer et al., 2002; Swann \& Bosson, 2008). An agreed identity for each party sets behavioral guides for subsequent social interactions (Ting-Toomey, 2005). As a result, expatriates may be uncertain about what social rules local employees will follow or may find it difficult to predict how they will behave. This increases uncertainty in their interactions and, in turn, reduces perceptions of trustworthiness. This negative effect is likely to be even stronger for ethnically different expatriates, because the perceived uncertainty might add to the already existing challenge of ethnic difference. Accordingly, we hypothesize

Hypothesis 1: The higher the level of EIC, the higher the perception of local employee trustworthiness by ethnically similar expatriates compared with ethnically different expatriates.

\section{Ethnic Similarity, Ethnic Identity Confirmation and Knowledge Acquisition}

The success of knowledge transfer is influenced by the knowledge source (Gupta \& Govindarajan, 2000), the knowledge seeker (Szulanski, 1996), the sender-receiver relationship (Simonin, 1999) and the transfer process (i.e., social interaction) (Hansen, 1999). As one step in knowledge transfer, knowledge acquisition is also influenced by these factors (Lazarova \& Tarique, 2005). High EIC can encourage knowledge acquisition. When high EIC is achieved (i.e. when ethnic identity is perceived as either important or unimportant by both parties), expatriates (i.e. the knowledge seeker) can benefit from feeling understood, accepted and respected (Polzer et al., 2002). Thus, they might feel confident in having more interactions and communication with local employees (i.e. the knowledge source) who confirm their ethnic identity. Frequent interactions smoothen the knowledge acquisition process, making it easier for knowledge to flow between the two parties (Gupta \& Govindarajan, 2000). Research on organizational newcomer learning has revealed frequent social interactions are an important channel from which newcomers can learn. Before establishing a close relationship with colleagues, newcomers can learn by 
observing other colleagues' attitudes and behaviors (Morrison, 1993). After a close relationship is established, newcomers might then be able to ask for information directly, which also relies on interactions (Morrison, 1993). Newcomers to MNCs' subsidiaries (Black, Mendenhall, \& Oddou, 1991), expatriates are expected to gain more knowledge from frequent interactions with local employees.

Again, the effect of EIC might interplay with ethnic similarity. Ethnic similarity not only encourages more social interactions between ethnically similar expatriates and local employees, but also ensures people's willingness to share knowledge, because both parties might feel obliged to support each other by sharing information (Doosje, Ellemers, \& Spears, 1995). In contrast, the positive effects of high EIC might be reduced for ethnically different expatriates because of perceived social distance. This distance can come from two sources. First, an ethnicity based out-group categorization can create a psychological distance between expatriates and local employees, thereby discouraging communication. Second, people experience social anxiety when interacting with others from different demographic groups (i.e., cultural, ethnic, and gender groups), because they are unsure how others will behave (Stephan \& Stephan, 1985), so they might be reluctant to interact with demographically different others. Therefore, we expect that high EIC encourages more knowledge acquisition for ethnically similar expatriates than for ethnically different expatriates.

In contrast, a lack of EIC is likely to generate opposite effects to what we have described above for both types of expatriates. If expatriates perceive local employees as not understanding their own view of ethnic identity, this might reduce expatriates intention to interact with local employees. As a result, a channel for knowledge exchange is blocked. If they view local employees as hostile, they might not be willing to seek knowledge from them. Therefore, we hypothesize that

Hypothesis 2: The higher the level of EIC, the higher the perception of knowledge acquisition by ethnically similar expatriates compared with ethnically different expatriates.

\section{The Mediating Role of Trustworthiness}

Whether or not people actively seek knowledge could depend on the benevolence of the source (Lee, 1997). Expatriates' perceived trustworthiness of local employees can facilitate expatriates' knowledge acquisition in two ways. First, expatriates are more likely to communicate with local employees who they perceive as trustworthy, and frequent interactions ensure an important knowledge transfer channel (Hansen, 1999; Kogut \& Zander, 1992; Nonaka, 1994). Second, expatriates are likely to seek knowledge directly 
from local employees because perceived trustworthiness indicates a high chance of success in acquiring the knowledge. Therefore, we hypothesize that expatriates' perception of local employees' trustworthiness mediates the association between ethnic (dis)similarity and expatriates' knowledge acquisition:

Hypothesis 3: The higher the level of EIC, the higher the perception of knowledge acquisition -- via perception of local employee trustworthiness -- by ethnically similar expatriates compared with ethnically different expatriates.

\section{Methods}

In 2012, we conducted a survey among white-collar employee dyads in Beijing, China. Each dyad consisted of an expatriate and his/her Chinese colleague. We made contact with expatriates through convenience and snowball sampling strategies (Dillman, 2007) at a variety of networking events. Two inclusion criteria were applied for the selection of expatriates: their employment in China was a temporary appointment made by the headquarters or another subsidiary, and they were not citizens of China. For ethnically similar expatriates, there was an additional criterion: they were ethnic Chinese by their own admission. Two hundred and eight expatriates who fulfilled the criteria were invited to participate in our survey. They were asked to select one of their Chinese colleagues to participate. A total of 292 questionnaires (including questionnaires from expatriates and local employees) were returned. After excluding incomplete responses and the ones that could not be matched in a pair, we were left with 128 valid pairs of (or 256) respondents. Although we did not specifically aim to have an equal number for ethnically similar and dissimilar expatriate pairs, we ended with 64 pairs in each group.

Hard copy surveys were hand-delivered by the principal researcher to expatriates' offices during the three days following networking events. Copies of the survey for both expatriates and their Chinese colleagues were included in each package. Expatriates received an English language copy of the questionnaire and Chinese employees received a Chinese version, which was translated by bilingual academics. Subsequently, focus groups of bilingual language experts and Chinese employees verified the accuracy of the translation. Expatriates were given two sealed envelopes, each containing a survey and a prepaid envelope. The name of the expatriate was printed on one envelope and "for your Chinese colleague" was printed on the other. The majority (nearly 80\%) of participants mailed back the questionnaire independently. In some cases (approximately 20\%), we collected the sealed envelopes from their offices. 
The expatriate respondents in the dataset belonged to a variety of North American and European ethnic groups. $61.7 \%$ of all expatriates were male and the median age was in the 30-34 category. Chinese employee respondents were expatriates' personal assistants, team members, or colleagues in the same office. $31.2 \%$ of the Chinese employees were male and the median age was in the 25-29 category. The time they had worked with the expatriate ranged between 1 and 108 months with an average of 1.3 years. The $43 \mathrm{MNCs}$ ' Chinese subsidiaries in which the respondents were employed operated in 24 industries, including accounting, architecture, consulting, energy, governmental organizations, graphic design, IT, law, the media, telecommunications, and real estate. They were fully or partially owned by organizations headquartered in a variety of countries, including Australia, Canada, France, Italy, the Netherlands, Norway, Spain, the United Kingdom and the United States.

In most cases, a 6-point Likert type scale was used. Since Chinese participants have been found to be less likely to choose extreme values in Likert-scales than Australians, Europeans and North Americans (Harzing, 2006; Yeh et al., 1998), to avoid response bias, a scale without a neutral point was used to encourage participants to express their opinions about statements given in the survey (Harzing, 2006).

\section{Measures}

Outcome variable: Knowledge acquisition (Perceived knowledge acquired by expatriates from Chinese local employees). We measured knowledge acquisition based on people's perceptions (Noorderhaven \& Harzing, 2009; Reiche, 2011). We identified three types of knowledge that expatriates might acquire from local employees: task-related, local- organization related and professional knowledge (Hocking, Brown, \& Harzing, 2004; Lazarova \& Tarique, 2005). We asked expatriates to evaluate how much information they had gained from their Chinese colleague in relation to these categories $(1=$ none $\ldots 6=$ very much). All three items loaded on one factor $(\alpha=0.75)$. A continuous measure was constructed by taking the mean of the values of the three responses.

Main effects: Ethnic similarity (between expatriates and local Chinese colleagues). The ethnic similarity of the expatriate and local employees was constructed as a dichotomous variable (ethnically similar expatriates $=1$, ethnically different expatriates $=$ $0)$.

Ethnic identity confirmation (Level of agreement between expatriate's ethnic identity importance self-view and Chinese colleague's view of the importance of expatriate's ethnic identity). As a new concept in the management literature, there is no existing scale to measure EIC. When Thatcher and Greer (2008) applied the self-verification mechanism to investigate social identities in work teams, they asked participants to rank the importance 
of multiple social identities on a Likert-scale. Following their example, we developed a similar approach to measure EIC. As this is the first time EIC has been measured, we treated perceived importance as a unidimensional concept, and used a single item to measure the perceived global importance of expatriates' ethnic identity. We believed this to be the most straightforward way to operationalize our definition (Wanous, Reichers, \& Hudy, 1997). Expatriates were asked to evaluate the following statement: "I believe that my ethnic identity is an important factor when I interact with this colleague at work" $(1=$ strongly disagree ... $6=$ strongly agree). Their Chinese colleagues were asked to evaluate the same statement in relation to their expatriate colleague: "His/her ethnic identity is an important factor when I interact with him/her at work." $(1=$ strongly disagree $\ldots 6=$ strongly agree) ${ }^{i}$. By calculating the value of the difference between the expatriate's score (self-view) and the colleague's score (other-view), then reverse-scoring the absolute difference, we were able to measure the level of perceptual confirmation between the two parties. The higher the score, the greater the confirmation. Although difference scores are limited in their application, in this situation they form a direct operationalization of our definition of EIC (Milton \& Westphal, 2005; Polzer et al., 2002). However, our measure does not distinguish between whether, for example, both dyadic partners rated the value as important or unimportant. Methods such as polynomial regression would be needed to test a complex, finer-grained model (Edwards, 1994, 2001; Edwards \& Parry, 1993) and we recommend that further studies use such an approach with larger samples.

Mediator: Trustworthiness (Expatriates' perception of Chinese colleagues' caring motives, promise fulfillment, integrity, and consistency). Mayer and his colleagues identify three dimensions of the concept of trustworthiness, including ability (trustee's skills and competence in a certain domain), benevolence (trustor's perception that the trustee will want do good to him/her) and integrity (trustor's perception that the trustee adheres to a set of principles that the trustor finds acceptable) (Mayer, Davis, \& Schoorman, 1995). However, these three dimensions are not necessarily relevant to all situations (Mayer \& Davis, 1999). In this context, high EIC affects expatriates' evaluations of local employees' attitudes in terms of whether or not they respect them, hold hostile attitudes towards them, or what principle they follow when interacting with them. As a result, we believe EIC is associated with the benevolence and integrity dimensions of trustworthiness, but not the ability dimension, which has more to do with expertise, skills or competence (Mayer et al., 1995). Therefore, in this study, we excluded the ability items and only adapted five benevolence and integrity items from the trustworthiness scale developed by Mayer, Davis and Schoorman (1995). Expatriates were asked about their level of agreement with the following statements concerning their colleague: "He/she would not knowingly do anything to hurt me (benevolence)"; "He/she really looks out for what is important for me (benevolence)"; "He/she will go out of his/her way to help me (benevolence)"; "I never have to wonder whether he/she will stick to his/her word (integrity)"; and "Moral principles seem to guide his/her behaviors (integrity)" $(1=$ strongly disagree $\ldots \quad 6=$ 
strongly agree). All items loaded on one factor $(\alpha=0.89)$. A continuous measure was constructed by taking the mean of the 5 items.

Control variables. Based on previous literature, expatriates' individual characteristics might affect their attitudes toward local employees; thus, we collected information on three control variables, including gender, age and expatriates' language proficiency (Noels, 2014; Polzer et al., 2002; Thatcher \& Greer, 2008). Additionally, dyadic level factors might also have affected the hypothesized outcome. Specifically, we collected information on expatriates' relationship length with local employees. In the survey, age was represented by 9 categories ranging from 20 to 65 . Gender was constructed as a dichotomous variable $(0=$ female, $1=$ male). Participants were asked how many months they had worked with their colleague. When each person in the dyad provided different information (43\% of dyads provided matched information, $27.5 \%$ of dyads provided information with a discrepancy of 1 month and $29.5 \%$ of dyads provided information with a discrepancy of more than 3 months), the mean value was calculated. Finally, language skills are an important indicator of identity (Noels, 2014). The Chinese language proficiency of expatriates, especially ethnically similar expatriates, might affect how their Chinese colleagues view them. Thus, a dichotomous variable was constructed $0=$ nonnative speaker level, 1 = native speaker level).

\section{Results}

We first assessed the discriminant validity of the two multi-item scales (i.e., perceived trustworthiness, and perceived knowledge acquisition) in the data. We used AMOS (Arbuckle, 1997) to conduct a confirmatory factor analysis with two latent variables representing perceived trustworthiness and perceived knowledge acquisition. The fit indices show a good fit to the data $\left(\chi^{2}=60.93, d f=38, p<0.05, C F I=0.96, I F I=0.96\right.$, $R M S E A=0.06)$. CFI and IFI values that are closer to 1 reflect better-fitting models (Byrne, 2001) and values of 0.08 or less for RMSEA indicate a good fit (Dilalla, 2000). In addition, we compared the two-factor model against a single-factor model (with a single latent variable representing both measures). The results show a poor fit with the single-factor model $\left(\chi^{2}=284.19, d f=42, p<0.001, C F I=0.70, I F I=0.71, R M S E A=0.17\right)$. The two-factor model fits the data significantly better than the single-factor model $\left(\Delta \chi^{2}=223.26, d f=4, p<\right.$ 0.01). These results confirm the discriminant validity of the two constructs drawn from the survey.

Since heterogeneity might have existed between ethnic Chinese expatriates and those of other ethnicities, we conducted invariance tests to ensure participants from the two groups associated survey items with the same constructs (configural invariance) and that the factor 
loadings of items reached invariance across groups (metric invariance) (Cheung \& Rensvold, 1999). The configural invariance test results show that the two groups employed the same conceptual frame of reference $\left(\chi^{2}=62.94, d f=38, p<0.05, C F I=0.95, T L I=0.92, R M S E A=\right.$ 0.07). Metric invariance test results show that factor loading invariance was also achieved $\left(\chi^{2}\right.$ $=65.24, d f=44, p<0.05, C F I=0.96, T L I=0.93, R M S E A=0.06$ ) (Hair et al., 1998). When constraints were added to the configural model, the overall model fit was not worsened $\left(\Delta \chi^{2}=\right.$ 2.01, $d f=6, p=\mathrm{ns})$.

Means, standard deviations and zero-order correlations for all variables are presented in Table I. We used hierarchical regression and PROCESS Model 8 (Hayes, 2013; Preacher, Rucker, \& Hayes, 2007) to test the hypotheses.

Table I: Correlation Matrix and Descriptive Statistics

\begin{tabular}{|c|c|c|c|c|c|c|c|c|c|c|}
\hline & Mean & SD & 1 & 2 & 3 & 4 & 5 & 6 & 7 & 8 \\
\hline 1. Relationship length & 16.47 & 19.71 & --- & & & & & & & \\
\hline 2. Gender & 0.62 & 0.49 & 0.16 & --- & & & & & & \\
\hline 3. Age & 3.05 & 1.76 & $0.53^{* *}$ & $0.20^{*}$ & --- & & & & & \\
\hline 4. Language proficiency & 0.17 & 0.38 & 0.02 & -0.07 & 0.13 & --- & & & & \\
\hline 5. Knowledge acquisition & 4.21 & 1.13 & $0.22^{*}$ & 0.03 & $0.24^{* *}$ & 0.15 & --- & & & \\
\hline 6. Ethnic similarity & 0.50 & 0.50 & -0.08 & -0.11 & -0.10 & $0.33^{* *}$ & -0.02 & --- & & \\
\hline 7. Ethnic identity confirmation & 0.00 & 1.15 & 0.04 & -0.01 & -0.02 & 0.03 & 0.06 & -0.02 & -- & \\
\hline 8.Trustworthiness & 4.83 & 0.87 & 0.17 & 0.11 & $0.24^{* *}$ & -0.10 & $0.38^{* *}$ & -0.05 & 0.09 & -- \\
\hline
\end{tabular}

Hypothesis 1 (The higher the level of EIC, the higher the perception of local employee trustworthiness by ethnically similar expatriates compared with ethnically different expatriates) was tested and results are presented in Table II. Controls and main effects were entered in Step 1 of the regression. The similarity coefficient was insignificant as expected ( $b=0.04, p=n s)$. The age coefficient was significant $(b=0.12, p<0.05)$, but all others were insignificant. The interaction term was included in Step 2 of the regression and the coefficient was significant and positive ( $\left.b=0.28, p<0.05, \Delta R^{2}=0.03, p<0.05\right)$. Figure 1 depicts the effect of EIC on the two types of expatriates. EIC generated higher levels of perceived trustworthiness toward local employees for ethnically similar expatriates $(b=0.22, p<0.05)$, but not for ethnically different expatriates $(b=0.06, p=\mathrm{ns})$. Hypothesis 1 was_supported. 
Table II: Expatriates' Perception of Local Employee Trustworthiness

\begin{tabular}{|c|c|c|}
\hline & Step 1 & Step 2 \\
\hline Constant & $4.43(0.19)^{* * *}$ & $4.44(0.19)^{* * *}$ \\
\hline \multicolumn{3}{|l|}{ Control variables } \\
\hline Relationship length & $0.00(0.00)$ & $0.00(0.00)$ \\
\hline Gender & $0.09(0.16)$ & $0.11(0.16)$ \\
\hline Age & $0.12(0.05)^{*}$ & $0.11(0.04)^{*}$ \\
\hline Language proficiency & $-0.32(0.25)$ & $-0.35(0.21)$ \\
\hline \multicolumn{3}{|l|}{ Main effects } \\
\hline Ethnic similarity (similarity = 1, dissimilarity =0) & $0.04(0.16)$ & $0.05(0.16)$ \\
\hline Ethnic identity confirmation & $0.07(0.08)$ & $-0.06(0.09)^{*}$ \\
\hline \multicolumn{3}{|l|}{ Interaction } \\
\hline Ethnic similarity ${ }^{*}$ ethnic identity confirmation & & $0.28(0.13)^{*}$ \\
\hline$\overline{\mathrm{R}^{2}}$ & 0.06 & $0.10^{*}$ \\
\hline Adjusted $\mathrm{R}^{2}$ & 0.02 & $0.05^{*}$ \\
\hline$\Delta \mathrm{R}^{2}$ & & $0.03^{*}$ \\
\hline
\end{tabular}

Note: $\mathrm{N}=128$. Ethnicity similarity=1, ethnic dissimilarity $=0$.

Table entries are unstandardized regression coefficients with standard errors in parentheses. ${ }^{* *} p<0.01 ;{ }^{*} p<0.05$

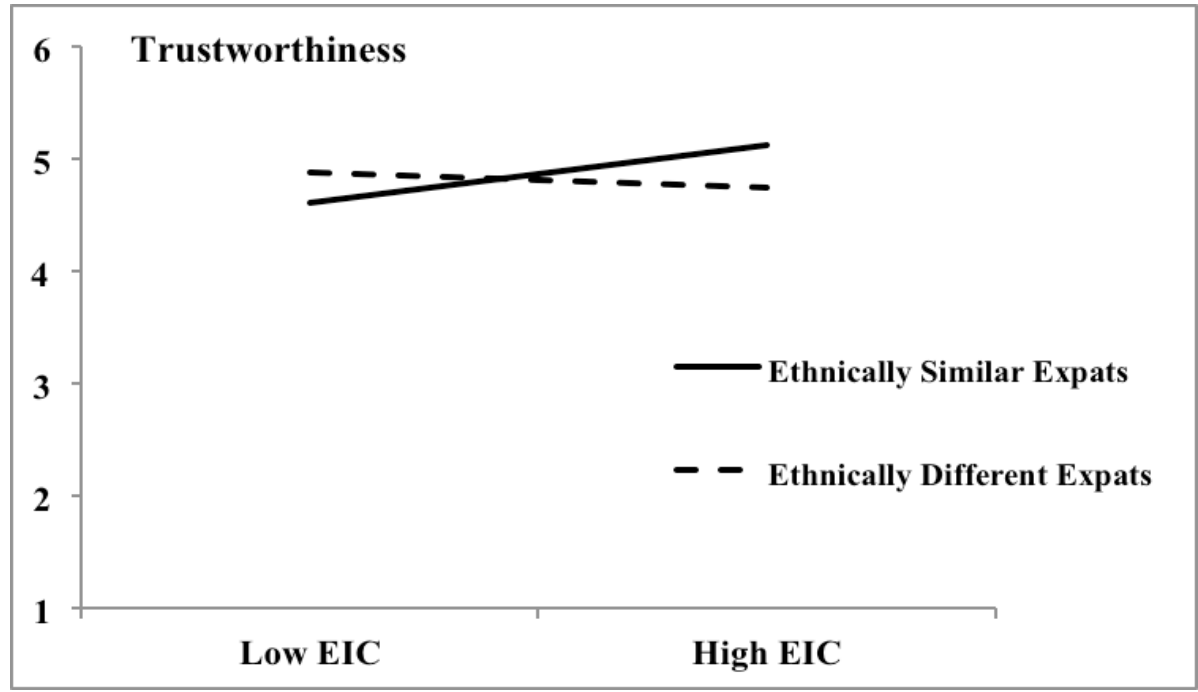

Figure 1: Profile Plot: Trustworthiness 
Hypothesis 2 (The higher the level of EIC, the higher the perception of knowledge acquisition by ethnically similar expatriates compared with ethnically different expatriates) was tested and the results are presented in Table III. Controls, main effects and the mediator were entered in Step 1 of the regression. The similarity coefficient was insignificant as expected $(b=-0.10, p=\mathrm{ns})$. The trustworthiness coefficient $(b=0.49, p<0.01)$ and language coefficient $(b=0.61, p<0.05)$ were significant, but all others were insignificant. The interaction term was included in Step 2 of the regression. In contrast to the findings for trustworthiness, the coefficient was significant and negative $\left(b=-0.43, p<0.01, \Delta R^{2}=0.03\right.$, $p<0.01$ ). Figure 2 depicts the effect of EIC on two types of expatriates. EIC generated higher levels of perception of knowledge acquisition for ethnically different expatriates $(b=$ $0.21, p<0.05$ ), but not for ethnically similar expatriates $(b=-0.22, p=\mathrm{ns}$ ) (shown in direct effects in Table IV). Hypothesis 2 was not supported.

\begin{tabular}{lcc}
\hline \multicolumn{2}{l}{ Table III: Expatriates' Perception of Knowledge Acquisition from Local Employees } \\
\hline \multicolumn{2}{l}{ Step 1 } & Step 2 \\
\hline Constant & $1.41(0.58)^{*}$ & $1.45(0.54)^{*}$ \\
$\quad$ Relationship length & $0.01(0.01)$ & $0.01(0.01)$ \\
Gender & $-0.11(0.20)$ & $-0.11(0.19)$ \\
Age & $0.03(0.07)$ & $0.04(0.06)$ \\
Language proficiency & $0.61(0.26)^{*}$ & $0.63(0.26)^{*}$ \\
$\quad$ Trustworthiness & $0.49(0.10)^{* *}$ & $0.52(0.11)^{* *}$ \\
Main effects & & \\
$\quad$ Ethnic similarity (similarity = 1, dissimilarity $=0)$ & $-0.10(0.20)$ & $-0.12(0.19)$ \\
$\quad$ Ethnic identity confirmation & $0.02(0.08)$ & $0.21(0.11)^{*}$ \\
Interaction & & $-0.43(0.16)^{* *}$ \\
$\quad$ Ethnic similarity * Ethnic identity confirmation & & $0.26^{* * *}$ \\
\hline $\mathrm{R}^{2}$ & $0.22^{* * *}$ & $0.21^{* * *}$ \\
Adjusted $\mathrm{R}^{2}$ & $0.18^{* * *}$ & $0.03^{* *}$ \\
$\Delta \mathrm{R}^{2}$ & & \\
\hline Note: N=128. & & \\
Table entries are unstandardized regression coefficients with standard errors in \\
parentheses.
\end{tabular}

\begin{tabular}{lccc}
\hline Table IV: Summary of Effects & & & \\
\hline & Direct effects & Indirect effects & Total effects \\
\hline Ethnically different expats & $0.21^{*}$ & -0.03 & 0.18 \\
Ethnically similar expats & -0.22 & $0.12^{*}$ & -0.10 \\
\hline Note: $\mathrm{N}=128 .{ }^{* *} p<0.01 ;{ }^{*} p<0.05$ & & & \\
\hline
\end{tabular}




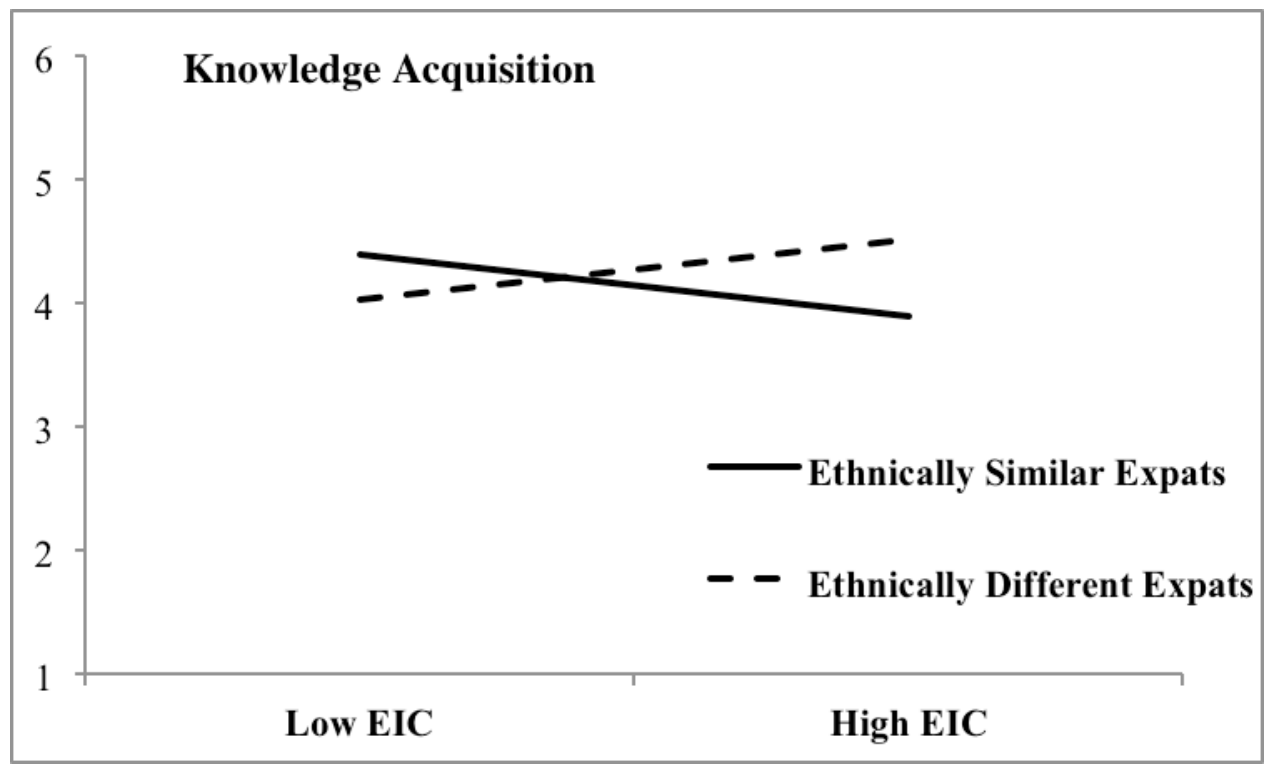

Figure 2: Profile Plot: Knowledge Acquisition

To test Hypothesis 3 (The higher the level of EIC, the higher the perception of knowledge acquisition -- via perception of local employee trustworthiness -- by ethnically similar expatriates compared with ethnically different expatriates), we used template 8 of the PROCESS macro for SPSS (Hayes, 2013; Preacher, Rucker \& Hayes, 2007) and a biascorrected bootstrapping confidence interval test. The indirect effect of the interaction was significant and positive: index of moderated mediation $=0.15$ (SE $=0.08,95 \%$ CI: 0.01 to 0.32). EIC generated higher levels of perception of knowledge acquisition via perceived local employee trustworthiness for ethnically similar expatriates $(b=0.12, p<0.05)$, but not for ethnically different expatriates $(b=-0.03, p=\mathrm{ns})$. We present the direct, indirect and total effects in Table IV. Hypothesis 3 was supported.

\section{Discussion}

Our research has revealed evidence to help explain an important conundrum in the expatriate literature, namely why sharing an ethnic identity with local employees does not always provide the expected advantages for expatriates. Our findings showed that while ethnic similarity had no significant association with expatriates' perception of local 
employee trustworthiness or knowledge acquisition, significant relationships became apparent when ethnic similarity was combined with EIC.

First, the higher the level of EIC for ethnically similar expatriates, the higher the level of perceived local employee trustworthiness. That is, ethnic similarity helps expatriates in establishing positive relationships with local employees, such as encouraging expatriates to view local employees as trustworthy if both parties reach a high level of agreement on the importance of expatriates' ethnic identity. Therefore, examining the similarities in demographic factors per se is not enough; we also need to consider the perceptual congruence between two parties on the demographic characteristic in question.

Second, an unanticipated finding is that the higher the level of EIC for ethnically different expatriates, the higher the level of perceived knowledge acquisition. This contradicts the expectations of research on ethnic dissimilarity (Mäkelä et al., 2012; Pichler et al., 2012; Toh \& DeNisi, 2007; Varma et al., 2011b). It may be that ethnic dissimilarity, language or cultural barriers limit the ability of expatriates to gain knowledge from society independently; thus, local employees become an important knowledge source for them. High EIC gives expatriates the perception that they are respected by local colleagues and can, thus, encourage expatriates to seek knowledge actively from their local colleagues. This can facilitate expatriates' learning from the different types of knowledge held by locals. Furthermore, high EIC can help local employees to identity the knowledge gap that these expatriates might have and purposefully provide knowledge to fill the gap (Leonardelli \& Toh, 2011). As a result, expatriates' expectations are met and so they believe that they have gained knowledge.

This finding does not deny the challenges caused by ethnic dissimilarity in the literature though. It is possible that local employees share certain types of knowledge with ethnically different expatriates, such as work-related knowledge, and general knowledge about the local culture and society, but withhold other types of knowledge, such as more sensitive knowledge. The items we used to measure knowledge acquisition all focused more on general knowledge (such as task-oriented knowledge, local organizational knowledge and professional knowledge) that might not be subject to the knowledge withholding effect related to ethnic out-group categorization. Future research could refine the measure of knowledge acquisition to investigate further the relationship between in-/out-group categorization and knowledge acquisition.

Finally, our most important finding is that for both types of expatriates, the higher the level of EIC, the higher the level of perceived knowledge acquisition; however, the underlying mechanisms differ. As previously discussed, ethnic dissimilarity is directly associated with expatriates' perception of knowledge acquisition, whereas for ethnically similar expatriates 
the association is indirect via their perception of local employees' trustworthiness. This indicates the effects of the interplay between ethnic (dis)similarity and EIC are not symmetrical. The mechanism is more complicated when expatriates share an ethnicity with local employees. Specifically, having their ethnic identity self-view confirmed by ethnically similar others can potentially encourage expatriates to trust local employees and this subsequently generates perceptions of knowledge acquisition. Our study, thus, reveals the complexity of how ethnic (dis)similarity works in expatriate-local employee interactions. The results clearly indicate the importance of considering the concept of EIC when examining objective demographic similarity.

\section{Theoretical Contributions}

To the expatriate literature. Our study advances the literature on how ethnic (dis)similarity affects expatriate-local employee interactions in two ways. First, although the role of demographic factors, such as race and ethnicity, has received considerable attention in the expatriate literature (Olsen \& Martins, 2009; Tung, 2008), relatively few studies have investigated the mechanisms underlying these factors other than similarity attraction and in-group/out-group categorization. With EIC, we offer an alternative mechanism explaining that objective ethnic identity per se might not be what influences interactions between expatriates and local employees, instead, social parties perceive the importance of their respective ethnic identities is crutial. Furthermore, EIC takes the perception of both social parties into consideration and thereby provides a new angle to understand the social impact of ethnic (dis)similarity in expatriate-local employee interactions. Second, our results reveal the complexity of ethnic (dis)similarity by revealing the asymmetrical effect it might create. The interaction between ethnic (dis)similarity and expatriates' EIC affects expatriates' perceived knowledge acquisition from local employees directly for ethnically different expatriates, but indirectly for ethnically similar expatriates. This advances our understanding of the role of ethnic (dis)similarity in expatriate-local employee interactions.

Furthermore, establishing positive relationships with local employees is related to expatriates' work adjustment and interaction adjustment (Black et al., 1991). When investigating expatriate-local employee interactions, current research primarily focuses on how expatriates' identity affects local employees, such as local employees' social categorization of expatriates or their attitudes towards expatriates (Pichler et al., 2012; Toh \& DeNisi, 2007; Varma et al., 2016 ; Varma, Toh, \& Budhwar, 2006). Researchers have rarely investigated expatriates' experiences in reaction to local employees' views of them. It is assumed that as long as local employees view expatriates' as in-groups or hold positive views toward expatriates, positive relationships between these two parties will be established. However, establishing positive relationships requires efforts from both parties 
and so how expatriates view local employees cannot be neglected. Our results contribute to this missing link in the literature by focusing on expatriates' perceptions of local employees' trustworthiness.

To the identity confirmation literature. In the field of management, the selfverification mechanism has been mainly applied in personal identity research (Milton \& Westphal, 2005; Polzer et al., 2002). Our study enriches this stream of research by providing evidence of its application to social identity, which so far has only received limited attention in the management literature (such as Thatcher \& Greer, 2008). We have also extended this line of research to the new context of expatriate management. This context provides an ideal opportunity to investigate the effect of EIC, a specific type of identity confirmation, because if some expatriates share an ethnicity with local employees but others do not, the ethnicity contrast is likely to become salient for local employees. They might use expatriates' ethnicity to make an ethnicity-based social categorization. Therefore, the concept of EIC can be used to examine the consequences when local employees' views of the expatriates' ethnic identity are divergent/convergent from expatriates' self-view.

\section{Practical Implications}

The results of our study can help HR managers understand whether or not employing ethnically similar expatriates is beneficial to the organization and to what extent ethnic (dis)similarity affects expatriates' performance. Firstly, based on our research, sharing an ethnicity with local employees could be a double-edged sword for expatriates. It could generate social benefits for expatriates when expatriates and local employees agree on the importance of their shared ethnic identity. However, conflicting views might generate different social expectations between the two parties, possibly inhibiting the establishment of positive relationships and preventing expatriates from gaining knowledge from local employees. To realize the benefits, MNCs need to provide help to both ethnically similar expatriates and local employees. For example, MNCs could provide identity management training to both expatriates and local employees.

The training could first develop expatriates' awareness of the role of identity and identity management. If expatriates are consciously aware of their identity choices and identity management behavior, they will be able to navigate purposefully the role of identity in social interactions. For example, if expatriates realize that local employees' views of the expatriate's ethnic identity might differ from their own, they can initiate identity negotiation with local employees. They could, for instance, use identity symbols (e.g., dress, choice of language, and decoration of office space) to let local employees know their personal identity choice; they could also talk with local employees directly to gain their 
understanding of their identity choices (Deaux \& Ethier, 1998; Swann \& Bosson, 2008). Thus, training on identity expression and identity negotiation skills could help expatriates to gain EIC and help ensure that their shared ethnic identity is a factor that facilitates rather than harms relationships.

Current organizational support programs tend to focus exclusively on expatriates (Caligiuri, Phillips, Lazarova, Tarique, \& Burgi, 2001; Harzing \& Pinnington, 2011). However, to achieve smooth interactions, both social parties need to make an effort to understand each other. MNCs could also improve local employees' awareness of the social implications of identity; help them to understand the possibly divergent identity views between them and expatriates, and encourage them to discuss openly their identity with expatriates. Finally, to ensure expatriates and local employees can exchange ideas about their identity freely, MNCs need to create an organizational environment that treats employees with diverse identities equally, encourages the free expression of identity, and respects employees' identity choices.

In terms of the effect of ethnic identity on expatriates' performance, our study reveals that both ethnically similar and ethnically dissimilar expatriates can gain knowledge from local employees, but through different mechanisms. Therefore, it is essential for MNCs to understand that expatriates with different ethnicities might face different challenges on international assignments. To succeed, different types of expatriates might need to behave differently. Consequently, a universal expatriate support program might not be appropriate. HR managers should provide tailored support to different types of expatriates to target the specific identity challenges they face. Although both types of expatriates require training on identity management skills, the focus of the training should differ. For example, training for ethnically similar expatriates could focus on how to avoid challenges caused by ethnic similarity. Expatriates need to be prepared for the social challenges related to their ethnicity to understand the influence of their ethnicity from the perspective of locals and to develop a personalized solution to deal with identity-related conflicts. In contrast, ethnically different expatriates could focus on how to benefit from being ethnically different, such as understanding the challenges and advantages of being ethnically different, understanding locals' expectations towards them, and developing skills to connect with locals.

\section{Limitations and Suggestions for Future Research}

Despite its important contributions, our study has several limitations that suggest fruitful avenues for future research. Firstly, we analyze individuals' perceptions toward the importance of an identity as if it is a conscious choice. However, we need to emphasize that identity management, such as making identity choices or switching between multiple 
identities, is not always conscious. In reality, people might not always realize when they are managing their identities, or they may not develop a set of systematic identity management strategies.

Secondly, when expatriates interact with local employees, both parties might desire to have their ethnic identity confirmed (Swann \& Bosson, 2008). Due to different cultural or ethnic backgrounds and organizational status, expatriates and local employees may react differently to low EIC. For simplicity, in this study we only investigated the effects of expatriates' EIC. Further research could study the effects of local employees' EIC, and compare the social consequences of local employees' EIC when they interact with ethnically similar expatriates as opposed to when they interact with ethnically different expatriates.

Thirdly, our research was conducted in a Chinese context and the focus was on the Chinese ethnic identity. However, due to historical or social circumstances, ethnic identity might mean different things to people in different ethnic groups (Phinney, 1990). As a result, they may react differently towards their ethnic identity self-view not being confirmed by social partners. Our empirical findings could have been affected by the special nature of the Chinese ethnic group and the history associated with it. Therefore, the impact of EIC needs to be investigated in studies involving other ethnic identities.

Fourthly, our research used a convenience sample by recruiting expatriates at social events. Participants worked for a large number of different organizations in different industries. One advantage of this sampling strategy is to minimize the influence of organizational or industry factors in the findings. Nevertheless, a future research opportunity might be to collect data from a small number of carefully chosen industries or MNCs from different home countries in order to examine the moderating role of these factors. Furthermore, when recruiting participants, we first identified expatriates and then asked them to invite one of their local colleagues to participate in the research. We specifically asked expatriates to select local employees based on the frequency of their work interaction and not based on their personal relationships. However, it is possible that they avoided inviting local employees with whom they had had conflicts. As a result, the sample might have suffered from selection bias. Future research could consider identifying expatriate-local employee dyads through HR departments, which could minimize the likelihood of such bias.

Finally, we included the four most relevant control variables in this research. Nonetheless, depending on the nature of the sample and research context, future researchers could include additional control variables. For example, they could control for participants' previous sojourn experience and their length of tenure in the MNC subsidiary as individual- 
level controls, as well as the type of relationship as dyadic controls, and organizational HR practices or organizational climate as organizational-level controls.

\section{Conclusion}

Driven by the phenomenon of employing ethnically similar expatriates, and the contradictory arguments on whether or not such expatriates are more effective than ethnically different expatriates when interacting with local employees, this study has compared and contrasted these two types of expatriates. By exploring the concept of EIC, defined as the level of agreement between how expatriates view the importance of their own ethnic identity and how local employees view it, we have provided evidence to show that both types of expatriates can gain knowledge from local employees, but that they follow different mechanisms. EIC provides a unique perspective to examine expatriate-local employee interactions in MNCs' subsidiaries and can, thus, generate significant future research opportunities to investigate expatriate-local employee interactions.

\section{References}

Alderfer, CP, \& Thomas, DA. (1988). 'The Significance of Race and Ethnicity for Understanding Organizational Behavior ', in C Cooper \& IT Robertson (eds), International Review of Industrial and Organizational Psychology Oxford, England: John Wiley \& Sons.

Antal, B-A. (2001). 'Expatriates' Contributions to Organizational Learning', Journal of General Management, 26: 4, 62-84.

Arbuckle, J. (1997). Amos users' guide, version 3.6: Marketing Division, SPSS Incorporated.

Ashforth, BE, \& Johnson, S. (2001). 'Which hat to wear? The relative salience of multiple identities in organizational contexts', Social identity processes in organizational contexts, 31-48.

Ashforth, BE, \& Mael, F. (1989). 'Social Identity Theory and the Organization', Academy of Management Review, 14: 1, 20-39.

Ashmore, RD, Deaux, K, \& McLaughlin-Volpe, T. (2004). 'An organizing framework for collective identity: Articulation and significance of multidimensionality', Psychological Bulletin, 130: 1, 80-114. 
Barreto, M, \& Ellemers, N. (2003). 'The effects of being categorised: The interplay between internal and external social identities', European review of social psychology, 14: 5, 139-170.

Björkman, I, \& Schapp, A. (1994). 'Outsiders in the middle kingdom: Expatriate managers in Chinese-Western joint ventures', European Management Journal, 12: 2, 147-153.

Black, JS, Mendenhall, M, \& Oddou, G. (1991). 'Toward a comprehensive model of international adjustment: An integration of multiple theoretical perspectives', Academy of Management Review, 16: 2, 291-317.

Bonache, J, Langinier, H, \& Zárraga-Oberty, C. (2016). 'Antecedents and effects of host country nationals negative stereotyping of corporate expatriates. A social identity analysis', Human Resource Management Review, 26: 1, 59-68.

Brewer, MB. (1979). 'In-group bias in the minimal intergroup situation: A cognitivemotivational analysis', Psychological Bulletin, 86: 2, 307-324.

Brewer, MB, \& Pierce, KP. (2005). 'Social Identity Complexity and Outgroup Tolerance', Personality and Social Psychology Bulletin, 31: 3, 428-437.

Burke, PJ. (2003). 'Relationships among multiple identities', in PJ Burke, TJ Owens, RT Serpe, \& PA Thoits (eds), Advances in Identity Theory and Research, New York, NY:US: Kluwer Academic/Plenum Publishers.

Burke, PJ, \& Stets, JE. (1999). 'Trust and commitment through self-verification', Social Psychology Quarterly, 62: 4, 347-366.

Byrne, B. (2001). Structural Equation Modeling with AMOS: Basic Concepts, Applications, and Programming, Mahwah, NJ: Lawrence Erlbaum Associates.

Caligiuri, PM, \& Lazarova, MB. (2001). 'Strategic repatriation policies to enhance global leadership development', in M Mendenhall, TG Kuehlmann, \& G Stahl (eds), Developing Global Business Leaders: Policies, Processes, and Innovations: Quorum Books.

Caligiuri, PM, Phillips, J, Lazarova, MB, Tarique, I, \& Burgi, P. (2001). 'The theory of met expectations applied to expatriate adjustment: The role of crosscultural training', International Journal of Human Resource Management, 12: 3, 357-372.

Chattopadhyay, P, Tluchowska, M, \& George, E. (2004). 'Identifying the ingroup: a closer look at the influence of demographic dissimilarity on employee social identity ', Academy of Management Review, 29: 2, 180-202. 
Cheung, GW, \& Rensvold, RB. (1999). 'Testing factorial invariance across groups: A reconceptualization and proposed new method', Journal of Management, 25: 1, 1-27.

Colquitt, JA, Scott, BA, \& LePine, JA. (2007). 'Trust, trustworthiness, and trust propensity: A meta-analytic test of their unique relationships with risk taking and job performance', Journal of Applied Psychology, 92: 4, 909-927.

Cooley, C. (1983). Human Nature and the Social Order, New Jersey: Transaction Publishers.

Deaux, K, \& Ethier, KA. (1998). 'Negotiating social identity', in JK Swim \& C Stangor (eds), Prejudice: The target's perspective., San Diego, CA, US: Academic Press.

Dilalla, LF. (2000). Structural Equation Modeling: Uses and Issues, San Diego: Academic Press.

Dillman, DA. (2007). Mail and Internet Surveys: The Tailored Design Method, NY: John Wiley and Sons.

Doosje, B, Ellemers, N, \& Spears, R. (1995). 'Perceived intragroup variability as a function of group status and identification', Journal of Experimental Social Psychology, 31: 5, 410-436.

Dowling, P, Festing, M, \& Engle, A. (2008). International Human Resource Management: Managing People in a Multinational Context, Melbourne: Australia: Tomsons.

Edwards, JR. (1994). 'Regression analysis as an alternative to difference scores', Journal of Management, 20: 3, 683-689.

Edwards, JR. (2001). 'Ten difference score myths', Organizational research methods, 4: 3, 265-287.

Edwards, JR, \& Parry, ME. (1993). 'On the use of polynomial regression equations as an alternative to differnece scores in organizational research ', Academy of Management Journal, 36: 6, 1577-1613.

Furuya, N, Stevens, MJ, Bird, A, Oddou, G, \& Mendenhall, M. (2009). 'Managing the learning and transfer of global management competence: Antecedents and outcomes of Japanese repatriation effectiveness', Journal of International Business Studies, 40: 2, 200-215.

Goodall, K, \& Warner, M. (1998). 'HRM dilemmas in China: the case of foreign-invested enterprises in Shanghai', Asia Pacific Business Review, 4: 4, 1-21. 
Gupta, AK, \& Govindarajan, V. (2000). 'Knowledge flows within multinational corporations', Strategic Management Journal, 21: 4, 473-496.

Hair, JF, Anderson, RE, Tatham, RL, \& William, C. (1998). 'Multivariate data analysis (5 ed)', Prentice Hall. Upper Saddle River, NJ: Prentice-Hall International

Hansen, MT. (1999). 'The search-transfer problem: The role of weak ties in sharing knowledge across organization subunits', Administrative Science Quarterly, 44: 1, 82-111.

Harzing, A-W. (1995). 'The persistent myth of high expatriate failure rates', The International Journal of Human Resource Management, 6: 2, 57-474.

Harzing, A-W. (2006). 'Response styles in cross-national survey research: A 26-country study', International Journal of Cross Cultural Management, 6: 2, 243-266.

Harzing, A-W, \& Pinnington, A. (Ed.) (2014). 'International Human Resource Management', in, London: SAGE Publications.

Harzing, A-W, Pudelko, MM, \& Reiche, BS. (2016). 'The bridgin role of expatriates and inpatriates in knowledge transfer in multinational corporations', Human Resource Management, 55: 4, 679-695.

Hayes, AF. (2013). 'Introduction to Mediation, Moderation, and Conditional Process Analysis : A Regression-Based Approach', in, New York: US: Guilford Publications.

Hocking, JB, Brown, M, \& Harzing, A-W. (2004). 'A knowledge transfer perspective of strategic assignment purposes and their path-dependent outcomes', International Journal of Human Resource Management, 15: 3, 565-586.

Hung, C. (1994). 'Business Mindsets and Styles of the Chinese in the People's Republic of China, Hong Kong, and Taiwan', The International Executive, 36: 2, 203-221.

Kogut, B, \& Zander, U. (1992). 'Knowledge of the firm, combinative capabilities, and the replication of technology', Organization Science, 3: 3, 383-397.

Lazarova, MB, \& Tarique, I. (2005). 'Knowledge transfer upon repatriation', Journal of World Business, 40: 4, 361-373.

Lee, F. (1997). 'When the going gets tough, do the tough ask for help? Help seeking and power motivation in organizations', Organizational Behavior Human Decision Process, 72, 336-363. 
Leonardelli, G, \& Toh, SM. (2011). 'Perceiving expatriate coworkers as foreigners encourages aid', Psychological science, 22: 1, 110-117.

Mahajan, A, \& Toh, SM. (2014). 'Facilitating expatriate adjustment: The role of adviceseeking from host country nationals', Journal of World Business, 49: 4, 476-487.

Mäkelä, K. (2007). 'Knowledge sharing through expatriate relationships', International Studies of Management \& Organization, 37: 3, 108-125.

Mäkelä, K, Andersson, U, \& Seppälä, T. (2012). 'Interpersonal similarity and knowledge sharing within multinational organizations', International Business Review, 21: 3, 439-451.

Mayer, R, Davis, J, \& Schoorman, F. (1995). 'An integrative model of organizational trust', Academy of Management Review, 20: 3, 709-734.

Mayer, R, \& Davis, JH. (1999). 'The effect of the performance appraisal system on trust for management: A field quasi-experiment', Journal of Applied Psychology, 84: 1, 123136.

McEllister, R. (1998). 'Recruitment and retention of managerial staff in China', in J Selmer (ed), International management in China: cross-cultural issues, New York: Routledge.

Milton, L, \& Westphal, J. (2005). 'Identity confirmation networks and cooperation in workgroups', Academy of Management Journal, 48: 2, 191-212.

Morrison, EW. (1993). 'Newcomer information seeking: Exploring types, modes, sources, and outcomes', The Academy of Management Journal, 36: 3, 557-589.

Noels, KA. (2014). 'Language variation and ethnic identity: A social psychological perspective', Language \& Communication, 35: March, 88-96.

Nonaka, I. (1994). 'A dynamic theory of organizational knowledge creation', Organization Science, 5: 1, 14-37.

Noorderhaven, N, \& Harzing, A-W. (2009). 'Knowledge-sharing and social interaction within MNEs', Journal of International Business Studies, 40: 5, 719-741.

Olsen, JE, \& Martins, LL. (2009). 'The effects of expatriate demographic characteristics on adjustment: A social identity approach', Human Resource Management, 48: 2, 311328. 
Phinney, JS. (1990). 'Ethnic identity in adolescents and adults: Review of research', Psychological Bulletin, 108: 3, 499-514.

Pichler, S, Varma, A, \& Budhwar, P. (2012). 'Antecedents and consequences of the social categorization of expatriates in India', The International Journal of Human Resource Management, 23: 5, 915-927.

Polzer, JT, Milton, LP, \& Swann, WB. (2002). 'Capitalizing on diversity: Interpersonal congruence in small work groups', Administrative Science Quarterly, 47: 2, 296-324.

Preacher, KJ, Rucker, DD, \& Hayes, AF. (2007). 'Addressing moderated mediation hypotheses: Theory, methods, and prescriptions', Multivariate Behavioral Research, 42: 1, 185-227.

Ramarajan, L. (2014). 'Past, present and future research on multiple identites: toward and intrapersonal network approach', The Academy of Management Annals, 8: 1, 589659.

Reiche, BS. (2007). 'The effect of international staffing practices on subsidiary staff retention in multinational corporations', International Journal of Human Resource Management, 18: 4, 523-536.

Reiche, BS. (2011). 'Knowledge transfer in multinationals: The role of inpatriates' boundary spanning', Human Resource Management, 50: 3, 365-389.

Selmer, J, \& Shiu, L. (1999). 'Coming home? Adjustment of Hong Kong Chinese expatriate business managers assigned to the People's Republic of China', International Journal of Intercultural Relations, 23: 3, 447-465.

Seyle, DC, \& Swann, WB. (2007). Being oneself in workplace: self-verification and identity in organization context, New Jersey: Lawrence Erlbaum Associates, Inc. Publishers.

Shaffer, MA, \& Harrison, DA. (1998). 'Expatriates' psychological withdrawal from international assignments: work, nonwork and family influences.', Personnel Psychology, 51: 1, 87-118.

Shaffer, MA, Kraimer, ML, Chen, Y-P, \& Bolino, MC. (2012). 'Choices, challenges, and career consequences of global work experiences', Journal of Management, 38: 4, 12821327.

Shen, Y, \& Kram, KE. (2011). 'Expatriates' developmental networks: network diversity, base, and support functions', Career Development International, 16: 6, 528-522. 
Simonin, BL. (1999). 'Ambiguity and the process of knowledge transfer in strategic alliances', Strategic Management Journal, 20: 7, 595-623.

Stephan, WG, \& Stephan, CW. (1985). 'Intergroup Anxiety', Journal of Social Issues, 41: 3, 157-175.

Stryker, S, \& Serpe, RT. (1994). 'Identity salience and psychological centrality: Equivalent, overlapping, or complementary concepts?', Social Psychology Quarterly, 57: 1, 1635.

Swann, WB, \& Bosson, JK. (2008). 'Identity negotiation: A theory of self and social interaction', in JP Oliver, Robins, Richard W. \& Pervin, Lawrence A. (ed), Handbook of personality psychology: Theory and research, New York: Guilford Press.

Swann, WB, \& Ely, RJ. (1984). 'A battle of wills: Self-verification versus behavioral confirmation', Journal of Personality and Social Psychology, 46: 6, 1287-1302.

Swann, WB, Rentfrow, PJ, \& Guinn, JS. (2003). 'Self-verification: The search for coherence', in MR Leary \& JP Tangney (eds), Handbook of Self and Identity., NY, US: Guilford Press.

Szulanski, G. (1996). 'Exploring internal stickiness: Impediments to the transfer of best practice within the firm', Strategic Management Journal, 17: 1, 27-43.

Tajfel, H. (1981). Human Groups and Social Categories, Cambridge: University Press Cambridge.

Thatcher, S, \& Greer, L. (2008). 'Does it really matter if you recognize who I am? The implications of identity comprehension for individuals in work teams', Journal of Management, 34: 1, 5-24.

Thite, M, Srinivasan, V, Harvey, M, \& Valk, R. (2009). 'Expatriates of host-country origin: 'Coming home to test the waters.", The International Journal of Human Resource Management, 20: 2, 269-285.

Ting-Toomey, S. (2005). 'Identity negotiation theory: Crossing cultural boundaries', in WB Gudykunst (ed), Theorizing about intercultural communication, Thousand Oaks, CA: Sage Publications.

Toh, SM, \& DeNisi, AS. (2005). 'A local perspective to expatriate success', Academy of Management Executive, 19: 1, 132-146. 
Toh, SM, \& DeNisi, AS. (2007). 'Host country nationals as socializing agents: a social identity approach', Journal of Organizational Behavior, 28: 3, 281-301.

Tsui, AS, \& O'Reilly, CA. (1989). 'Beyond simple demographic effects: the importance of relational demography in superior-subordinate dyads', Academy of Management Journal, 32: 2, 402-423.

Tsui, AS, Porter, LW, \& Egan, TD. (2002). 'When both similarities and dissimilarities matter: Extending the concept of relational demography', Human Relations, 55: 8, 899-929.

Tung, RL. (2008). 'Do race and gender matter in international assignments to/from Asia Pacific? An exploratory study of attitudes among Chinese and Korean executives', Human Resource Management, 47: 1, 91-110.

Turner, JC. (1982). 'Towards a cognitive redefinition of the social group', Social identity and intergroup relations, 1, 15-40.

Vance, CM, Vaiman, V, \& Andersen, T. (2009). 'The vital liaison role of host country nationals in MNC knowledge management', Human Resource Management. Special Issue: HRM and knowledge processes, 48: 4, 649-659.

Varma, A, Aycan, Z, Budhwar, P, Pichler, S, Uygur, U, \& Paluch, R. (2016 ). 'Host country nationals support for expatriates: an investigation in Turkey', European Journal of International Management, 10(6), 605-623.

Varma, A, Pichler, S, \& Budhwar, P. (2011a). 'The relationship between expatriate job level and host country national categorization: an investigation in the UK', International Journal of Human Resource Management, 22: 1, 103-120.

Varma, A, Pichler, S, \& Budhwar, P. (2011b). 'The relationship between expatriate job level and host country national categorization: an investigation in the UK', The International Journal of Human Resource Management, 22: 01, 103-120.

Varma, A, Toh, SM, \& Budhwar, P. (2006). 'A new perspective on the female expatriate experience: The role of host country national categorization', Journal of World Business, 41: 2, 112-120.

Wanous, JP, Reichers, AE, \& Hudy, MJ. (1997). 'Overall job satisfaction: How good are single-item measures?', Journal of Applied Psychology, 82: 2, 247-252.

Yeh, LL, Kim, KO, Chompreeda, P, Rimkeeree, H, Yaud, NJN, \& Lundahl, DS. (1998). 'Comparison in use of the 9-point hedonic scale between Americans, Chinese, Koreans, and Thai', Food quality and preference, 9: 6, 413-419. 


\section{Notes}

\footnotetext{
${ }^{\text {i }}$ To validate the reliability of this single-item scale, we subsequently developed a 5-item scale, which included this item and 4 new items to measure the perceived importance of expatriates' ethnic identity and tested the scale in two additional samples. The aim was to examine the reliability of the multi-item scale and to verify to what extent the original item was correlated with the mean of the 4 new items using two new samples. Sample 1 included local Chinese employees who work for MNC subsidiaries in China $(N=160)$. In sample 2, we used international students who worked with Chinese students on project teams in China as representatives for expatriates. This is because international students share some common features with expatriates, such as being sojourners working with local people in a foreign country. Budget constraints were another reason; because expatriates were spread across multiple organizations, it was not practical for us to find enough representatives of both types of expatriates to validate the measure. This sample included students who were ethnic Chinese (i.e. Malaysian Chinese, Norwegian Chinese, Spanish Chinese, Singaporean Chinese and Indonesian Chinese) $(N=16)$, and students who were not ethnic Chinese $(N=13)$. The reliability of the multi-item measure was high (Sample 1: $\alpha=0.86$; Sample 2: $\alpha=0.92)$, and the original item was highly correlated with the mean of the other 4 items (Sample 1: $r=0.64, p<0.001$; Sample 2: $r=$ $0.74, p<0.001)$. Our results, thus, show that the single item used in this article can be used as representative of a multi-item measure.
} 